Théodore Monod: The geological constitution of the Mauritanian Adrar.

Alexandre Guillerd and Pierre Etrillard : The persistance of fluorescin in the soil. The influence of ferruginous formations.

Nrcolas Stoyko: The periodicity in the irregularity of the rotation of the earth.

Arthur Brunel and Robert Echevin: The evolution of nitrogen, appearance of allantoinase and of urease in the germination of rust (Agrostemma Githago).

JOSEPH LEFèvRE: The reversal of polarity produced in cuttings of Salix.

A. Guieysse-Pellissier : The presence of striated muscular fibre in the pulmonary arteries of the rat and the mouse.

Maurice Villaret, Henti Bénard, Louis Justin Besancon and Mlle Andrée Abadi: The mathematical study of the kinetics of hæmolysis (kinelysis).

LÉon KÉPINov : The antiglycogenolytic action of insulin.

RenÉ Salgues: Nutrient leucocytosis in reptiles in bad conditions of captivity.

JEAN LoISELEUR : The adsorption of polypeptides by proteins. The behaviour of a solution of peptone.

\section{Forthcoming Event}

Faraday Society, September 13-15.-General discussion on "Reaction Kinetics" to be held in the University of Manchester.

\section{Appointments Vacant}

APPLICATrONS are invited for the following appointments, on or before the dates mentioned:

ASSISTANT LECTURER AND A DFMONSTRATOR IN ELECTRICAL ENGINEERING in the Imperial College of Science and Technology (City and Guilds College), Prince Consort Road, S.W.7-Secretary (September 13).

Assistant Lecturer in Electrical ENgineering in the Manchester Municipal College of Technology-The Registrar (September 20).

Lecturer in Physical Chemistry (Grade II) in the University of Bristol-Secretary and Registrar (September 24).

SoIL CHEmist for the Rubber Research Scheme, Agalawatta, Ceylon-The Chairman (November 15).

INSPECTORS OF MINES in the Colonial Mines Service-The Director of Recruitment (Colonial Service), 2 Richmond Terrace, Whitehall, S.W.1.

\section{Official Publications Received}

\section{Great Britain and Ireland}

Forestry Commission. Special Leaflet No. 1: Pit-Props. Pp. 8. (London : Forestry Commission.)

Iron and Steel Institute. Special Report No. 18: Reports upon Blast-Furnace Field Tests. 1: An Investigation of a Blast-Furnace smelting principally Lincolnshire Ores at the Frodingham Works of the Appleby-Frodingham Steel Co. Ltd. Pp. v +98 . 10s. Special Report No. 19: Foamed Blast-Furnace Slag. By Dr. T. W. Parker. Forestry Commission. Bulletin No, 14: Forestry Practice; a Summary of Methods of Establishing Forest Nurseries and Plantations with Advice on other Forestry Questions for Owners and Agents. Revised edition. Pp. 99. (London: H.M. Stationery Office.) 1s. $6 d$. Revised edition. Pp. 99. (London: H.M. Stationery Office.) 1s. $6 d$.
net. The Journal of the Institute of Metals. Vol. 60. Edited by G. Shaw Scott. Pp. $456+59$ plates. (London: Institute of Metals.) [238 Air Ministry : Meteorological Office. Southport Auxiliary Observatory (the Fernley Observatory of the Corporation of Southport). Annual Report, and Result; of Meteorological Observations, for the Year 1936. By Alfred Goodwill. Pp. 32. (Southport: Fernley observatory ; London: Air Ministry.)
Air Ministry: Aeronautical Research Committee : Reports and Memoranda. No. 1760 (2458 and 2459): Progress of Experiments in Aero-Engine Exhaust Silencing. By A. W. Morley. Pp. 18. 28. 6d. net. No. 1761 (2362): The Stress in Certain Tubes of Rectangular Cross Section under Torque. By D. Williams. Pp. 34. 4s. 6d. net. No. $1766(2607)$ : Experiments on a Sphere at Critical Reynolds Numbers. By A. Fage. Pp. 20. 3s. net. No. $1771(2722)$ : Tests of Four Airscrew Sections in the Compressed Air Tunnel. By D. H Williams, A. F. Brown and E. Smyth. Pp. 20. 3s, net. No. 1774 (2675): Aerodynamic Characteristics of Tapered Wings with Flaps and Slots. By Dr. S. H. Hollingdale. Pp. 43. 6s. net. No. $1779(2693)$ Experiments on the Use of a Static Tube in the Wing Wake and Sxpert Pitot Tube in the Leading Edge as an Airspeed Indicator. B Short Pitot Tube in the Leading Edge as an Airspeed Indicator. By
the Aerodynamics Staff, R.A.E. Pp. 6. 1s. net. (London: H.M.


Other Countries

Government Museum, Trivandrum. Administration Report for the Year 1111 M.E. Pp. 8. A concise Guide for Visitors. Pp. 8

U.S. Treasury Department: Coast Guard. Bulletin No. 19: The Marion and General Green Expeditions to Davis Strait and Labrado Sea under direction of the United States Coast Guard 1928-1931-19331934-1935. Scientiflc Results, Part 2: Physical Oceanography. Pp. vi +259 . (Washington, D.C.: Government Printing Office.) 75 cents.

Report of the Kodaikanal Observatory for the Ycar 1936. Pp. 4 (Delhi: Manager of Publications.) 3 annas; $4 d$. Madras Fisheries Department. Administration Report for the Year 1935-36. By Dr. B. Sundara Raj. Pp. iii $+68+3$. (Madras: Government Press.) 8 annas.

Meteorological Office. Note No, 17 : Climatic Notes-New Zealand Districts. By Dr. E. Kídson. Pp. 32. (Wellington: Government

Statens Meteorologisl-Hydrografiska Anstalt Tillgör A 1936. Arsberättelse för 1936 Pr. 19 Arsbok 18 soversikt over våderlek och vattentillgang. Pp. $76.2 .50 \mathrm{kr}$. (11s.) Nederbörden i Sverige. Pp. 15. 2.50 kr. (Stockholm: Staten
Meteorologisk-Hydeograflska Anstalt.) Anales del Museo Argentino de Ciencias naturales. Antropologia, Etnologia y Arquelogia, Publicación No. 78: Fuéguidos y Láguidos, posición actual de la raza Paleo-americana o de Lagoa Santa. Por J. Imbelloni. Pp. 79-104. Publicación No. 79: Deformación del cráneo en la región de los Atacamenos y Diaguitas. Por el Prof. Ricardo E. Latcham. Pp. 105-124. (Buenos Aires: Museo Argentino
de Ciencias naturales.)
[238

Report Of the Botanical Survey of India for $1935-36$.
Calcutta: Government of India Press.)

Commonwealth of Australia: Council for Scientiflc and Industrial Research. Bulletin No. 105: Investigations on the Associated Growth of Herbage Plants. By H. C. Trumble, T. H. Strong and R. E. Shapter Pp. $40+10$ plates. Bulletin No. 106: Investigations on "Spotted Pp. $40+10$ plates. Bulletin No. 106: Investigations on "Spotted Pp. 32. (Melbourne: : Government Printer.)
[238 U.S. Department of the Interior: Office of Education. Bulletin, 1937, No. 2: Trends in Secondary Eiducation. Pp. vi +44.10 cents Pamphlet No. 71 : An Annotated Bibliography on the Education and Psychology of Exceptional Children. Prepared by Elise H. Martens and Florence E. Reynolds. Pp. iii +42 . 10 cents. (Washington, D.C. :
Government Printing Office.)

Classifled List of Smithsonian Publications available for Distribution, August 10, 1937. (Publication 3394.) Pp. vi + 35. (Washington, D.C. Smithsonian Institution.)

Smithsonian Miscellaneous Collections. Vol. 96, No. 1: Archeology of St. Lawrence Island, Alaska. By Henry B. Collins, Jr. (Publication 3411). Pp. xi $+431+84$ plates. (Washington, D.C.: Smithsonian
Institution.)

Proceedings of the United States National Museum. Vol. 84, No. 3017: Revision of the North American Species of Ichneumon-Flies of the Genus Exetastes Gravenhorst. By R. A. Cushman. Pp, 243-312+ plates 16-21. Vol. 84, No. 3018: A Revision of the Clapper Rails (Rallus longirostris Boddaert). By Harry C. Oberholser. Pp. 313-354. Vol. 84, No. 3019: Moths of the Genus Rupela (Pyralididæ: Schoenobiinæ). By Carl Heinrich. Pp. 355-388 + plates 22-33. (Washington, D.C.: Government Printing office.) Nyasaland Protectorate. Annual Report of the Forestry Department for the Year ended 31st December 1936. Pp. 18. (Zomba:
Government Printer.)

Publikationer fra det Danske Meteorologiska Institut. Communications magnétiques, etc., No. 18: Contribution à la connaissance de l'effet magnétique de l'électriflcation des chemins de fer. Par Dr. Mauritius Institute Bulletin. Vol. 1, Part 2: Revised Catalogue of the Testaceous Mollusca of Mauritius and its Dependencies. By R. Viader. Pp. xiii +111 . (Port Louis: Government Printer.) [238 Bernice P. Bishop Museum. Bulletin 143: Revision of the Polynesian Species of Peperomia. By T. G. Yuncker. Pp. 73. Bulletin 144: Polynesian Botanical Bibliography, 1773-1935. By E. D. Merrill. Pp. 194. Bulletin 145: Ethnology of Uvea (Wallis Island). By Edwin G. Burrows. Pp. $176+8$ plates. Bulletin 147 : The Genus Gouldia (Rubiaceæ). By F. Raymond Fosberg. Pp. $82+3$ plates. Bulletin 149: Report of the Director for 1936. By Peter H. Buck (Te Rangi Hiroa). Pp. 33. (Honolulu: Bernice P. Bishop Museum.) [248

Nutrition. Final Report of the Mixed Committee of the League of Nations on the Relation of Nutrition to Health, Agricultural and Economic Policy. (Official No.: A.13.1937.II.A.) Pp. 327. (Geneva: League of Nations; London: George Allen and Unwin, Ltd.) 7s. $6 d$.
[248

Proceedings of the California Academy of Science, Fourth Series. Vol. 23, No. 9: Mammals of Death Valley. By Joseph Grinnell Pp. 115-169. (San Francisco: California Academy of Sciences.)
[248 